\title{
Krigenes finansieringssystemer
}

- en formanalyse af krig og kredit i kølvandet på Clausewitz

I 1752 forudså Preussens kong Frederik den Store i sit politiske testamente, at Frankrig ville bryde sammen, hvis landet ikke lærte at håndtere sine finanser. Hermed mente denne krigsherre, den formodentlig mest geniale strateg nogensinde, først og fremmest, at Frankrig ikke måtte føre ufinansierede krige: "Holland tæller i dag næppe som stormagt, fordi regeringen tynges af gæld, og hvad endnu værre er, ikke længere kan opnå kredit. Mens Frankrig vil geråde i forfald trods sin magtfylde, hvis regeringen fortsætter med som nu at misholde sin økonomi." (Friedrich der Große 1986: 7).

Temaet for denne artikel er, hvorledes kriges revolutioneringer og forskydningsformer strukturelt kobler sig til finansielle revolutioner. Siden Frederik har genuine analyser af koblingen mellem krigsstrategi og finansieringsmuligheder ikke fået nogen praktisk betydning. Krigens system, det politiske system og finansieringens økonomiske system var blevet funktionelt uddifferentieret i 1700-tallet, hvilket betød, at krig primært tænktes taktisk ud fra krigens behov; økonomi og finansiering ud fra økonomiske systemer og markedets præmisser; og politik blev i kølvandet på folkesuverænitetsdoktrinen siden Jean-Jacques Rousseau fortolket ud fra det politiskes selvbestemmelse sui generis. Dette betød samtidig, at de enkelte systemer hver især blev blinde for deres indbyrdes strukturelle sammenkobling. Politisk bestemte man ganske vist militærudgifterne, men krig forandrer de udgifter til uigenkendelighed eftersom krige som regel altid bliver dyrere og længere end beregnet.

I denne artikel vil jeg, med USAs - og verdens - finansielle krise som udgangspunkt, illustrere den strukturelle kobling mellem krig og finansieringssystemer. Dette vil jeg gøre ved at koble Niklas Luhmanns teori om funktionssystemers selvreference (Luhmann 1984; 1991; 2007) med den mest klassiske af alle krigsanalytikere, Carl von Clausewitz, og dennes teori om krigens tyngdepunktsforskydninger. Ved at koble Luhmann og 
Clausewitz vil jeg vise, hvordan tyngdepunktet forskyder sig fra slagmarken og i retning af finansiel opslidning.

Først vil jeg illustrere USAs nuværende situation som det aktuelle udgangspunkt for analysen, og derefter vise, med udgangspunkt i den historiske sociologis fokus på krig og statsdannelse, hvordan man kan forstå den nuværende krise ud fra forskydningen i krigens tyngdepunkt.

\section{Det amerikanske eksempel}

Aktuelt har USA i februar 2012 en offentlig gæld på over 15,4 tusind milliarder dollars. Det er en gæld, der stiger med 2,3 million dollars i minuttet og i 2016 beregnes at være vokset til 20 tusind milliarder dollars, hvorefter den skal afvikles med et forst langsomt og siden eksponentielt stigende renteniveau (Stiglitz 2010). Med mindre da den rigeste halvdel af amerikanerne forinden accepterer at betale betydeligt mere i skat - hvilket ganske vist opsuger midler og således forstærker en recession, der ganske vist kan afvikles ved offentlige produktive investeringer (Stiglitz 2010: 300). Intet tyder på, at det vil ske. Alternativt kan de offentlige udgifter beskæres med så kontraktiv en finanspolitik, at den med sikkerhed vil medføre en recession. Samtidig vil de kolossale veteranomkostninger fra Irak- og Afghanistankrigene for alvor vælte ind over landets sociale budgetter og lægge dæmpere på USAs produktive ydeevne (Stiglitz \& Bilmes 2008).

USA skal håndtere en gammel og velkendt lære om en politisk styret kobling mellem krigenes systemer og finansielle systemer. Ingen skal sige, at det finansielle sammenbrud, USA står over for, har været uforudsigeligt. Da USA gik ind i Afghanistan samtidigt med, at landet planlagde Irakkrigen, var landets fremtid bundet til meget bestemte scenarier. Med Elena Esposito og Niklas Luhmann kan man pege på en finansielt set risikabel tidsbinding (Luhmann 1991; Esposito 2010: 30-56). USA foretog dermed det som historikeren Paul Kennedy har betegnet som et krigsfinansielt "overstretch", som forinden også var blevet foretaget af Sovjetunionen, Tyskland, Storbritannien, Napoleons Frankrig, l'Ancien Régime i Frankrig, Sverige, og af habsburgernes rige (Kennedy 1989; Harste 2011). Typisk for tiden før 11. september 2001 og helt op til efteråret 2003 var der analytikere som Henry Nau (2001), der mente, at Kennedy tog fejl: USAs magt var den eneste mulige supermagt, og Kina ville ikke kunne udfordre USAs finansielle magt. Nau forsøgte at kritisere hele Kennedys gennem- 
gang af 500 års statsdannelse, men overså som mange andre (f.eks. Ikenberry 2002), det simple i advarslen om ikke at overdrive selvtilliden til egne finanser og militærmagt. Advarslerne havde ellers været legio (Mack 1975; Lind et al. 1989; Metz \& Kievit 1995; Knox \& Murray 2001: 175-194; Mearsheimer \& Walt 2003; Record 2002; Mann 2003). USA havde planlagt at kunne føre to mellemstore krige samtidigt, men også at krigene ville tage kort tid. De havde ikke planlagt at planer bryder sammen, når krige begynder (Yarger 2006). Pointen er at store, langvarige krige fører til tab af budgetkontrol og dertil fører såvel finanskriser som moralske velfærdskriser i den omkostningstunge behandling af veteraner.

\section{Kreditgejstens betydning}

I 1795 beskrev Immanuel Kant, som så mange andre tænkere før og efter ham, hvordan den såkaldte 'handelsgejst' fremmer freden. Hans krigsøkonomiske analyse er dog en helt anden:

Der må ikke udvikles en statsskyld i relation til den ydre statshandel. At staten til støtte for landets økonomi tyr til indenlandske eller udenlandske hjælpekilder kan ikke dadles. Disse kunne tjene til forbedring af vejnettet, nybosættelser, fødevaremagasiner til brug i år med misvækst osv. Men et driftigt handelsfolk har i dette århundrede gjort den åndrige opfindelse at bruge kreditsystemet i staternes magtbalance. Gælden kan vokse til det uoverskuelige, uden at aktuelle fordringer bringes i fare, da ikke alle kan gøre deres krav gældende samtidigt. Denne pengenes magt er farlig, da den er en magt til at føre krig, en magt der overgår, hvad alle andre stater tilsammen kan opbyde (Kant 1977b: 198-199).

Kant henviser her til Englands finansielle revolution, og det forhold at England siden tiden omkring 1700 finansierede sine krige på det europæiske kontinent og sin flådeopbygning med et kreditsystem af en type, der $i$ princippet eksternaliserede omkostningerne fra beslutningstagerne selv og fra beslutningsøjeblikket selv. Den moderne verdens finansieringssystem stammer fra den tid.

I disciplinen historisk sociologi har man længe gjort opmærksom på kriges finansielle belastninger. Men de fornødne teoretiske midler til at gennemtænke koblingen mellem krigens system og finansieringssystemet har været utilstrækkelige. Max Webers skrifter om denne kobling, skrevet 
under Første Verdenskrig, har været blandt de bedste bud. Problemet er også beskrevet i analyser af begge verdenskrigene, idet der findes mange analyser, som på enkel vis sammenligner produktionsevne og (u)balancer i våbenbeholdning, mandskab etc. (Strachan 2004; Harrison 1998). De, der beskæftigede sig med organisering af våben- og ressourceopkøb, arbejdede med en problemstilling, der også er kendt for historikere og politologer.

Det er noget påfaldende, at ingen politisk og militær strateg siden Frederik den Store har udviklet analyser af og forholdt sig til, hvordan store og langvarige kriges kampe forskydes til kampe om logistisk opslidning og ressourceforbrug og derfra videre til konflikter om finansiering, beskatning og kredit. Kant intonerede ellers betydningen af denne kobling i Über den Gemeinspruch - Das mag in der Theorie richtig sein, tangt aber nicht für die Praxis (Om ordsproget - Det der er rigtigt i teorien, duer ikke i praksis) fra 1793. Titlen rummer mange paradokser og antageligvis i denne sammenhæng også den, at krig kan finansieres, selv når midlerne til dem tilsyneladende er opbrugt, hvilket dog rummer risici:

I stater med stadig stærkere hang til at vokse sig større på andres bekostninger, vil den fremadskridende kultur gennem list eller med vold således mangfoldiggøre krigene og vil (ved blivende fortjeneste) gennem stadig mere mangfoldiggjorte og udstyrede hære, opretholdt stående og disciplinerede, således føre til stadig højere omkostninger; idet priserne på alle behov fortsat vil vokse, uden at en dertil proportional fremadskridende tilvækst i fremstillingen af metaller kan afhjælpes; og idet ingen fred varer så længe, at opsparingen herunder kommer på lige fod med omkostningsforbruget ved den næste krige, så vil opfindelsen af statsskyld udgøre et sindrigt, men i sidste ende et selvfornægtende hjælpemiddel; og således vil det, en god vilje havde kunnet gøre, men ikke gjorde, slutteligt føre til afmagt (Kant 1977a: 170).

Ligesom Kant i 1793 kunne konstatere, at Frankrig som supermagt ville komme i afmagt, har vi siden 2001 kunnet se, hvorledes USAs unipolære almagt baseres på et ikke-bæredygtigt kreditsystem, som fører til supermagtens afmagt.

Siden det take-off i militære revolutioner, der begyndte med skydevåben, fæstninger og krigsskibe med de italienske krige (1492-1525), har krige og stats- og magtopbygning stort set bestået i stadig mere raffinerede militære, organisatoriske, finansielle, videnskabelige og retlige revolutio- 
ner, der alle skulle håndtere krigenes uendelige kompleksitetsstigning og behov for systemdannelser, herunder ikke mindst deres behov for finansieringssystemer og kreditsystemer.

\section{Tabet af budgetkontrol}

I 1500-tallet blev man i stadig større grad opmærksom på, at krig forbindes med finansiering. Den gang blev krigstider og fredstider opfattet som årstidernes gang: de vekslede og skiftede som højkonjunktur og lavkonjunktur (Cornette 1993). Krig var blevet beskrevet som en allestedsnærværende mulighed, som stormvejr og regnvejr. Men krigene ændredes og blev stadig mere professionelle, mere veludstyrede og velorganiserede, og når de tog til, var det ikke som blæsevejr, men som stormvejr og orkaner, der rev alt op med rode. Krig skabte eksplosive forandringer. Man har i historisk sociologi hæftet sig ved væksten i hærstørrelserne fra hære på 8-20.000 mand i 1400-tallet til stadig større hære med op til 130.000 under Trediveårskrigen (1618-48) og 400.000 under Ludvig den 14. sidst i 1600-tallet (Lynn 1995: 125). Det fokus er imidlertid delvis misvisende. Den eksplosive forandring var nemlig langt større.

De mindre tidlige hære var oftest kun indkaldte i få dage, mens eksempelvis Ludvig den XIVs enorme hær var indkaldt permanent og derudover indkvarteret $\mathrm{i}$ bekostelige fæstninger og udstyret med uniformer, skydevåben, artilleri, ammunition, magasiner og fødevarelagre, våbenfabrikker, umådelige mængder køretøjer og heste og ikke mindst vejsystemer, broer, kroer og hestestalde. Omkostningerne under krigene, og herunder oprustningen i fredstider, steg således eksplosivt fra begyndelsen af 1500-tallet og de næste 300 år. I oversigter ser man ofte stigningen $i$ tal for indskrevne hære, men de tal er for det første såkaldte 'teoretiske tal', der ikke tager højde for den omfattende desertering (specielt når lønudbetalingerne udeblev). Soldater var langt mere formelt indplacerede, ligesom officerer og bureaukrater blev ansatte frem for blot udnævnte (Schulze 1995: 268) For det andet inkluderede alt rosset også handlende, familier, oppassere, horer, betlere og andre, der levede af krigen, forsynede den og forsynede sig af den.

Man kan altså med modifikationer lave et regnestykke over, hvor antal mand gange antal dage gange udrustning giver os den samlede hæromkostning. Hertil skal også lægges udviklingen af forsyningsveje, broer og 
brobelægning og fæstninger. Hele dette regnestykke angiver en enorm vækst i alle tre områder, der således ganget med hinanden udviser eksplosivitet $\mathrm{i}$ finansiering, tilmed når man yderligere fokuserer på den traditionelt oversete flådeudvikling. Vi må med andre ord gange den sociale dimensions mandtal med den materielle dimensions forsyningsmæssige antal og med tidens permanens. I stedet for de tabeller over forskellige landes hærstørrelser, der sædvanligvis fremføres i den historiske sociologis fremstillinger og $\mathrm{i}$ analyser af de såkaldte militære revolutioner (Downing 1992: 96; Tallet 1992: 17; Tilly 1992: 79; Parker 1995: 44; 1996:61; Lynn 1995), må vi flytte abstraktionsniveauet et niveau op og generalisere ud fra en enkel. Denne kalkule kan dertil også beskriver den strukturelle kobling mellem hærstørrelse og det behov, der historisk har vist sig for vækst i statslige skatteadministrationer og igen altså i de statslige forvaltningers mandskab (antal ansatte), deres permanens (heltidsbeskæftigelse) og deres udstyr (bygninger m.v.).

Langvarige nedslidningskrige skaber i dag omtrent samme type finansieringsproblem, som denne forenklede beskrivelse af klassisk krigsfinansiering antyder. Disse finansieringsproblemer forstærkes endvidere, når de store omkostninger til veteraner sætter ind. Ved hjælp af Niklas Luhmann vil jeg her udvikle en andenordensiagttagelse af hvilke systemer, der dengang og nu er sat i spil i koblingen mellem krigens systemer og finansieringssystemerne. Først vil jeg behandle Carl von Clausewitz' klassiske analyse af forskydninger i krigens 'tyngdepunkt' eller 'gravitationscenter' (Schwerpunkt) for at se på, hvordan det kan føre i retning af finansiel opslidning.

\section{Forskydningen i kriges tyngdepunkt mod finansieringssystemet}

Krig er ikke, hvad man først tror, hævder Clausewitz. Krig kan ikke planlægges, eller mere præcist udtrykt: strateger og taktikere kan i bedste fald planlægge, at de må ændre planer, for krig er fyldt med friktion, og en af friktionerne er, at modstanderne forsøger at sætte ens planer ud af kraft, hvilket altid lykkes mere eller mindre fuldstændigt. Et populært og paradoksalt slogan er, at 'sandheden er krigens første offer', men i nærværende sammenhæng er det nok så væsentligt, at finanserne kan være krigens andet offer. For at få greb om den problemstilling kan man bruge Clause- 
witz' teori om forskydninger af tyngdepunkt eller gravitationscenter.

Clausewitz' pointe er, at krige også er opslidningskrige. Krigens kulminationspunkt for den angribende må ikke være der, hvor hans eget tyngdepunkt er kommet ud af ligevægt, fordi tyngdepunktet typisk ligger der, hvor forsyningslinjerne kobles til hærstyrkerne. Krigen flytter sig fra en kamp om at overtage og nedkæmpe på slagmarken til i stedet at nedslide ved et umådeligt ressourceforbrug.

I den clausewitzske optik er pointen yderst paradoksal. På den ene side udgør kontrollen med ressourceforbruget nok så reelt den kobling, der muliggør, at det politiske system kan styre krigens system svarende til Clausewitz' berømte definition af, at "krigen er fortsættelsen af politik, men i et andet medium" (Clausewitz 1952: 888). Krigens forsyningslinjer kan kontrolleres via fødekæderne for nye rekrutter, moral, udstyr (mad, ammunition, transportmidler osv.) og ikke mindst finanser. På den anden side fører denne instrumentelle målstyring alligevel til et paradoks, fordi budgetterne historisk set nærmest altid omgående er blevet sprængt i en grad, der langt overstiger gængse katastrofale udviklinger i offentlige budgetter. Første Verdenskrig er et berømt eksempel på denne budgeteksplosion. Tyskland var, siden Frederik den Store, kendt for at have de største krigsbudgetter rede til langvarig krig i Frederiks klassiske formel til fire års krig (Friedrich der Große 1986: 37), men i 1914 var kassen tom efter kun tre uger! (Strachan 2004: 47ff).

Clausewitz lancerer et utal af definitioner af, hvad krigens 'væsen' er. Centralt står dog hans analyse af krig som en form for 'vekselvirkning'. Faktisk taler han om tre former for vekselvirkninger, som jeg her vil aftegne vha. Niklas Luhmanns teori om sociale kommunikationssystemer (Luhmann 1984: 112). Jeg vil her udlægge den luhmannianske aktualisering af Clausewitz' tilgang lidt enklere end andre, tyske, tilgange (Brücher 2011: 91-155; Beckmann 2011: 87-102; Matuszek 2007):

- Krigen har altid en genstand, dvs. et materielt og substantiel sagsforhold, som der kæmpes om. Krigen kan aftegnes af, hvad der konfliktes om, og hvad der ikke konfliktes om. Dette er den forste distinktion, der kan iagttages ud fra et skel mellem, hvad der er inkluderet, og hvad der er ekskluderet. Dette er krigens saglige dimension, der giver krigen en materiel form for mening. Mange kriges genstand har været territorier, der har været særligt ressourcefyldte eller muliggjort store skatteindtægter, samt 
udgjort strategiske transportveje.

- Krigen foregår altid som en vekselvirkning mellem parter. Krigen rummer en dobbelt kontingens mellem alter og ego. Nogle er parter, og andre er ikke parter. Krigen inkluderer nogle og ekskluderer andre som ikke-krigsførende i en distinktion, der både retter sig mod aktører som stater og mod aktører som soldater i modsætning til civile. Dette udgør krigens sociale dimension. Krigen får kun tilskrevet mening, hvis den har en sådan social dimension og retning og består i form af nedkæmpelsen af modpartens autonome viljesdannelse.

- Krigen foregår altid indenfor en bestemt tidsligt afgrænset periode. Krigen rummer et før, et under, og et efter. Den begynder, kulminerer og slutter. Krigen selekterer altså krigstider fra fredstider og inkluderer og ekskluderer i den tidslige dimension. Krigen får kun tilskrevet mening, hvis den kan se frem til freden, og har således kun mening hvis den har en tidslig dimension.

Med Luhmann kan man kalde de tre former her for førsteordensiagttagelse af krigens abstrakte form (Luhmann 2007). I den klassiske form for symmetrisk krigsførelse har man typisk hæftet sig ved dette taktiske niveau, men Clausewitz' afgørende pointe er, at den 'virkelige' krig også udgør en kamp om krigens former og bliver til en kamp om det, man ud fra Luhmanns systemteori vil kalde andenordensiagttagelse. Det vil sige, at de tre former også sættes i spil:

- Den saglige dimension forskyder sit tyngdepunkt fra at være umiddelbart substantielt identificérbart til først at vedrøre forsyningslinjer, logistik, kommunikationscentre, troppernes moralske habitus og kampevne og til at vedrøre militær produktionsevne, indsats af ressourcer, finansieringsevne, kreditsystemer, den offentlige opinions opbakning, hjemmefrontens støtte, propaganda, herunder TV, internet, krigsfortællinger og krigsæstetik.

- Den sociale dimension forskydes, så kombattanter omfatter civile, mens soldater kan optræde som civile (f.eks. som spioner, partisaner, guerilla og terrorister), ligesom de kan omfatte modpartens dissidenter og krigskritikere, herunder den offentlige opinion, som også berøres af tyngdepunktsforskydningen i den saglige dimension. Ligeledes kan internationale støtter og såvel aktive som passive alliancepartnere involveres. 
Krigen kan legitimeres på egen side og delegitimeres på modpartens side eller hos modpartens komplekst sammensatte fora af støtter.

- Den tidslige dimension forskydes, så det for det første bliver uklart, hvornår kampen begyndte (herunder kan den sociale dimension så forskyde anerkendelsen af, hvem der begyndte). For det andet kan krigens vedvarenhed og forlængelse fortabe sig, så tåge og friktion ikke blot er materiel og politisk, men også temporal. Krigen bliver, som Weber indså om Første Verdenskrig, til en nedslidningskrig. Der sker en nedbrydning af den moralske vilje til at fortsætte dels med angreb og dels med forsvar. 'Afgørelsens time' kan ophøre med at eksistere i nogen som helst identificérbar forstand, hvilket nedslider såvel kampmoral, beskatningsvillighed som kreditmuligheder. Konsekvensen har historisk set typisk vist sig som kreditkriser. Men den tidslige dimension kan også forskyde krigens tyngdepunkt til at ligge længe efter en fredsslutning, eksempelvis i omkostningen til veteraner og manglen på deres og de pårørendes arbejdsmæssige ydeevne, hvilket præventivt forhindrer fremtidige offensiver.

Det er nærmest en tautologisk iagttagelse, at i større og langvarige krige bevæger førsteordensiagttagelsen over i andenordensiagttagelsen af krigens former. Krigen kan kæmpe om sin egen form og tyngdepunktet forskyder sig fra slagmarkens regulære krig til kamp om opbakning, ressourcer etc. Fokus her er som allerede nævnt tyngdepunktsforskydningen i retning af den strukturelle kobling til finansieringssystemerne.

I 2010 hævdede oberstløjtnant Thomas McCabe i en artikel i War Studies Institute's tidsskrift Parameters, at al-Qaeda helt havde misforstået den 'strategi', der skulle føres i en kamp overfor USA. Det må siges at være en tvivlsom påstand, idet USA lige netop kom til at skabe det finansielle overstretch, som Paul Kennedy advarede mod, og som faktisk nævnes af McCabe som al-Qaedas udgangspunkt, uden at han er i stand til at iagttage Kennedys finansstrategiske pointe (Harste 2011). At man ikke har taget denne historiske og teoretiske lektion alvorligt har fået alvorlige konsekvenser. 


\section{De politiske og national-statslige konsekvenser}

Med Den Franske Revolution fordredes skat som en universel pligt ud fra kravet om lighed for (skatte)loven. Aristokraterne skulle også betale skat. I New England blev den amerikanske skattetradition imidlertid grundlagt med The Tea Party Protest i 1773: amerikanerne anså (te)skat for et frihedsberøvende krav fra den despotiske engelske besættelsesmagt.

Udviklingen af kreditsystemer skabte store forskydninger mellem de stænder, der var aktive, henholdsvis passive, i krediteringen. På det europæiske kontinent forblev det en dyr lektie, at krig koster. I USA blev lektien gjort med Borgerkrigen (1861-65), hvis veteranudgifter mange år efter krigens afslutning voksede til over $40 \%$ af det føderale budget i 1890 erne.

Kreditsystemerne blev afgørende i 1900-tallets verdenskrige (Porter 1994; Kindleberger 1984; Germain 1997; Eichengreen 2007; Frieden 2006; Ahamed 2009). Udover skat og kredit kan krige imidlertid også kortvarigt - finansieres ved udstedelse af betalingsmidler. Denne sidste strategi anvendte Tyskland på nok så berømt vis under og efter Første Verdenskrig. Udenfor temmelig snævre finansieringshistorikeres kredse er det imidlertid ofte overset, at den usammenligneligt dyreste af alle krige, Anden Verdenskrig, for Vestens vedkommende blev finansieret ved, at USA indløste størstedelen af den enorme krigsgæld ved at udstede dollars og betale for den med dollars, som var dollars indløselige med guld. Dollaren blev reservevaluta frem for sølv og guld, der håbløst forældet gjorde verdenshandelen afhængig af tilfældige opdagelser af guldminer i eksempelvis Sydafrika. Bretton Woods-systemets løsning var genial - så længe USA ikke misbrugte det dels ved at importere ubegrænset, nemlig efter først at have betalt (med dollarudstedelse) for andre landes import af amerikanske varer (herunder gennem Marshall-hjælpen), dels ved at skabe eksplosivt ufinansierede udgifter som eksempelvis ufinansierede krige. Med Vietnamkrigen kunne dollaren ikke længere indløses med guld. Derefter forblev dollaren alligevel reservevaluta, men uden materiel reference herfor andet end tillid til landets fremtidige betalingsevne.

I Irak og Afghanistan har Vesten haft store troppestyrker i mange år og med meget logistik. Det fordrer skattestigning, skatteadministration, voksende stat, og i tillæg vil tabet af den type krigsfinansiering føre til krigsgæld og forsøg på kunstige rentesænkninger (som USAs Federal Reserve's direktør Alan Greenspan forsvarede). Lave renter fører til belåning, eksempelvis af huse, gældssætning og overforbrug. Sænker man samtidig 
skatterne, får man en gigantisk finanskrise, når gælden (forbrugernes og staternes) ikke kan betales tilbage, banker bliver insolvente, og finanskrisen accelereres (Stiglitz \& Bilmes 2008: 126-127).

Forventningerne til tabet af budgetkontrol accelereres imidlertid også af, at kalkulationen i moderne tid ser lidt anderledes ud og rummer en større skygge af omkostninger, der rækker langt frem i tiden, efter det man klassisk forstod ved en krigsslutning. Problemet er, at krige fører til gigantiske veteranomkostninger. Veteraner bliver mindre produktive end andre, og siden verdenskrigene har det vist sig, at mange flere end de fysisk sårede også er behandlingskrævende. Det har skabt enorme velfærdsstatslige programmer i de fleste moderne lande (Geyer 1983; Pedersen 1993). Siden Vietnamkrigen har det moderne velfærdssamfunds individualiserede forståelse og behandling af frivillige soldaters også ført til forstærkede former for eksempelvis posttraumatisk stress syndrom (PTSD), hvilket kan siges at blive forstærket i de tilfælde, hvor krigene må anses for uløste og eventuelt tabte. Der er omtrent 6000 selvmord årligt blandt amerikanske krigsveteraner (Shinseki 2011). USA vil i 2014 have haft omtrent 2,5 millioner soldater udstationeret i Irak og Afghanistan, hvoraf halvdelen ifølge Department of Veterans Affairs søger om invalidehjælp (Duggan 2009). Der er tale om unge mennesker, der er støttekrævende i eksempelvis 40 år. Forskellen ('opportunity costs') til normalt aktive ligger for den støtteog behandlingskrævende som modelberegning på eksempelvis halvdelen af gennemsnitsindtægten (200.000 kr.). Det er 20.000 milliarder kroner (Stiglitz \& Bilmes 2008). Bush-regeringen havde beregnet Irakkrigen til at koste 500 milliarder kroner, men som allerede nævnt, er det vigtigste, man kan planlægge om krig, at ens planer går i stykker. Som jeg har prøvet at illustrere, bliver krige altid længere og dyrere end forventet og langvarige krige kæmper om sin egen form og forskyder sit tyngdepunkt i retning af finansiel opslidning.

Med Afghanistan- og Irakkrigenes samlede globale omkostninger fra 2001-2011 på måske 10.000 milliarder dollars (Stiglitz \& Bilmes 2008: 130, 138), synes krige endnu engang at have ledt en supermagt ud i det finansielle "overstretch" og den tyngdepunktsforskydning, som ifølge Paul Kennedy historisk udgør supermagternes militære fald (Kennedy 1988; Harste 2011). 


\section{Litteratur}

Ahamed, Liaquat (2009): Lords of Finance, London: Penguin.

Beckmann, Rasmus (2011): Clausewitz, trifft Luhmann, Wiesbaden: VS Verlag.

Brücher, Gertrud (2011): Gewaltspiralen, Wiesbaden: VS Verlag.

Clausewitz, Carl von (1952, [1832]): Vom Kriege, Bonn: Dümmler.

Cornette, Joël (1993): Le roi de guerre, Paris: Payot.

Downing, Brian (1992): The Military Revolution and Political Change - Origins of Democracy and Autocracy in Early Modern Europe, New Jersey: Princeton University Press.

Duggan, Sean (2009): "Veteran Demographics" i Lawrence Korb, Peter Juul \& Max Bergmann, Serving America's Veterans, Connecticut: Praeger.

Eichengreen, Barry (2007): Global Imbalances and the Lessons of Bretton Woods, Cambridge, MA: MIT Press.

Esposito, Elena (2010): Die Zukunft der Futures - Die Zeit des Geldes in Finanzwelt und Gesellschaft, Heidelberg: Carl-Auer Verlag.

Friedrich der Große (1986, [1752]): Das politisches Testament von 1752, Stuttgart: Reclam.

Frieden, Jeffrey (2006): Global Capitalism - Its Rise and Fall in the Twentieth Century, New York: Norton.

Germain, Randall (1997): The International Organization of Credit, Cambridge: Cambridge University Press.

Geyer, Michael (1983): "Ein Vorbote des Wohlfahrtsstaates - Die Kriegsopferversongung in Frankreich, Deutschland und Grossbritannien nach dem Ersten Weltkrieg“", Geschichte und Gesellschaft, Band 9: s. 230-277.

Harrison, Mark (red.) (1998): The economics of World War II, Cambridge: Cambridge University Press.

Harste, Gorm (2011): “Asymmetriens Fælde” i Marlene Fenger-Grøndahl (red.), 11. September, Århus: Aarhus Universitetsforlag.

Ikenberry, John (red.) (2002): America Unrivaled, Ithaca: Cornell University Press.

Kant, Immanuel (1977a, [1793]): "Über den Gemeinspruch - Das mag in der Theorie richtig sein, taugt aber nicht für die Praxis“ i Immanuel Kant, Werkausgabe Band XI, Frankfurt: Suhrkamp.

Kant, Immanuel (1977b, [1795]): “Zum ewigen Frieden“ i Immanuel Kant, Werkausgabe Band XI, Frankfurt: Suhrkamp.

Kennedy, Paul (1989): The Rise and Fall of the Great Powers, London: Fontana.

Kindleberger, Charles P. (1984): A Financial History of Western Europe, London: Allen \& Unwin.

Knox, MacGregor \& Murray, Williamson (red.) (2001): The Dynamics of Military Revolution 1300-2050, Cambridge: Cambridge University Press.

Lind, William et al. (1989): “The Changing Face of War - Into the Fourth Generation", Marine Corps Gazette, October, s. 22-26, http://www.dni.net/fcs/4th_gen_war_gazette.htm. 
Luhmann, Niklas (1984): Soziale Systeme, Frankfurt: Suhrkamp.

Luhmann, Niklas (1991): Soziologie des Riskikos, Berlin: De Gruyter.

Luhmann, Niklas (2007): Indforing i systemteorien, København: Unge Pædagoger.

Lynn, John (1995): "Recalculating French Army Growth During the Grand Siècle, 16101715” i Clifford Rogers (red.), The Military Revolution Debate, Boulder: Westview Press.

Mack, Andrew (1975): "Why Big Nations lose Small Wars - The Politics of Asymmetric Conflict”, World Politics 27 (2), s. 175-200.

Mann, Michael (2003): Incoherent Empire, New York: Verso.

Matuszek, Krysztof (2007): Der Krieg als autopoietisches System, Wiesbaden: VS Verlag.

McCabe, Thomas (2010): “The Strategic Failures of al Qaeda”, Parameters, Spring, s. 60-61.

Mearsheimer, John J. \& Walt, Stephen (2003): “An unnecessary war”, Foreign Policy, Jan/Feb, http://www.mtholyoke.edu/acad/intrel/bush/walt.htm.

Metz, Steven \& Kievit, James (1995): Strategy and the Revolution in Military Affairs - From Theory to Policy, Carlisle: Strategic Studies Institute.

Nau, Henry (2001). "Why 'The Rise and Fall of Great Powers' was wrong”, Review of International Studies, Vol. 27, s. 579-592.

Parker, Geofrrey (1995): “The 'Military Revolution,' 1560-1660 - A Myth?” i Clifford Rodgers (red.), The Military Revolution Debate, Boulder: Westview Press.

Parker, Geoffrey (1996, [1988]): The Military Revolution, Cambridge: Cambridge University Press.

Pedersen, Susan (1993): Family, Dependence and the Origin of the Welfare State, 1914-1945, Cambridge: Cambridge University Press.

Porter, Bruce (1994): War and the Rise of the State, New York: The Free Press.

Record, Jeffrey (2002): "Collapsed Countries, Causality Dread, and the new American Way of War", Parameters, US Army War College Quarterly, Spring, s. 4-23.

Schulze, Winfried (1995): "The Emergence and Consolidation of the "Tax State"' i Richard Bonney (red.), Economic Systems and State Finance, Oxford: Clarendon.

Shinseki, Eric (2011): Strategic Plan Refresh, 2011-2015, Washington: U.S. Department of Veterans Affairs.

Stiglitz, Joseph E.\& Bilmes, Linda J. (2008): The Three Trillion Dollar War - The True Cost of the Iraq War, New York: W.W. Norton and Company Inc.

Stiglitz, Joseph (2010): Freefall - America, Free Markets, and the Sinking of the World Economy, New York: Norton.

Strachan, Hew (2004): Financing the First World War, Oxford: Oxford University Press.

Tallett, Frank (1992): War and Society in Early-Modern Europe 1495-1715, London: Routledge. Tilly, Charles (1992): Coercion, Capital, and European States, AD 990-1992, Oxford: Blackwell. Yarger, Harry (2006): The Strategic Theory for the 21 $1^{\text {st }}$ Century, Carlisle: Strategic Studies Institute. 
